\title{
Saliva as a Diagnostic Tool for AB0 Blood Group Determination
}

\author{
F Gilmiyarova ${ }^{1 *}$, V Kuzmicheva ${ }^{1}$, E Ryskina ${ }^{2}$, N Kolotyeva ${ }^{1}$, 0 Gusyakova ${ }^{1}$, G Baisheva ${ }^{1}$ and \\ E Gilmiyarov ${ }^{1}$ \\ ${ }^{1}$ Federal State Budgetary Educational Institution of Higher Education, Samara State Medical University of the Ministry of \\ Healthcare of the Russian Federation, Russia
}

${ }^{2}$ Federal State Autonomous Educational Institution of Higher Education, Peoples' Friendship University of Russia, Russia

*Corresponding author: Gilmiyarova Frida, Samara State Medical University; address: 89 Chapaevskaya St., Samara, Russian Federation, Russia

\section{ARTICLE INFO}

Received: 幽 March 27, 2020

Published: 蔧 April 06, 2020

Citation: F Gilmiyarova, V Kuzmicheva, E Ryskina, N Kolotyeva, O Gusyakova, et al. Saliva as a Diagnostic Tool for AB0 Blood Group Determination. Biomed J Sci \& Tech Res 26(5)-2020. BJSTR. MS.ID.004424.

Abbreviations: RBC: Red Blood Cells; MCV: Mean Corpuscular Volume; Hb: Hemoglobin; MCH: Mean Corpuscular Hemoglobin; MCHC: Mean Corpuscular Hemoglobin Concentration
ABSTRACT

The simplicity and convenience of collecting saliva, as well as its component composition, make this biological fluid a common object of laboratory research, in particular for detecting the nucleic acids of viruses and bacteria, monitoring certain clinical conditions. The range of clinical situations where to use saliva as a diagnostic tool is becoming increasingly widespread and also includes determination of secretory status. The aim of this paper is to characterize the secretory status of the oral fluid, depending on the presence of group-specific antigens of the AB0 system. Antigens of the $\mathrm{AB} 0$ system are commonly considered in the context of immunohematology and transfusiology, however, there are new data about the significance of the research in saliva. These results are interesting not only for practical medicine as a convenient and non-invasive diagnostic method, but also for solving fundamental problems. Determining glycome of patient's oral fluid as an individual specific parameter will help to create a new personalized approach in preclinical diagnosis and develop preventive measures for many known diseases.

Keywords: hemato-salivary Barrier; Blood Groups; ABO System; Saliva; Salivadiagnostic

\section{Introduction}

Constancy of internal environment of an organism is a necessary condition for normal functioning and vital activity of all its systems. Homeostasis maintenance is based on numerous physiological mechanisms, one of which is the presence of histohematic barriers. For the first time the term "histo-hematic barrier" was used in 1929 by the Soviet scientist L.S. Stern who defined it as a plastic, mobile mechanism taking part in maintaining the constancy of the internal environment and function, which can be regulated by exogenous and endogenous biologically active substances [1]. By means of histo-hematic barriers the passage of electrolytes, proteins with small molecular weight, products of metabolism, factors of specific and non-specific protection from blood to tissue fluid is carried out, which promotes breathing, trophism, cells proliferation and differentiation, elimination of unnecessary components formed during metabolism from organs and tissues [2]. Histo-hematic barriers maintain their functions due to their selective permeability, which is determined by the peculiarities of their structure. Hemato-encephalic (blood-brain barrier), hematoplacental, hemato-ophthalmic (blood-ocular barrier), and hematosalivary barriers are distinguished by their localization [3].

We are interested in studying the structure and properties of the hemato-salivary barrier. It represents a mechanism regulating selective intake of substances from blood into oral liquid [4]. The hemato-salivary barrier is formed by endothelium lining the capillary wall, myoepithelial, secretory cells, cells of salivary gland outlet ducts [5]. In recent years, interest in rapid and less invasive 
diagnostic tests has increased in progression, resulting in extensive studies of oral fluid as an object of clinical diagnosis. Oral fluid has some advantages over blood and urine, the two most commonly used biological fluids in the laboratory. Oral fluids can be obtained easily and noninvasively, with lower protein content and a less complex component composition compared to blood serum [6]. Oral fluid is successfully used in kidney disease monitoring, cardiometabolic risk prevention, forensic medicine, and drug abuse monitoring, as well as in the diagnosis of Human Immunodeficiency Virus (HIV) and other nucleic acids of bacteria and viruses, even including COVID-19. According to the latest data, there is a significant correlation between $\mathrm{AB} 0$ blood group affiliation and predisposition to COVID-19. It was shown in the study including more than 2000 patients that A(II) blood group carriers are more likely to have the disease [7]. The objective of this study is to characterize the secretory status of oral fluid depending on the presence of groupspecific antigens according to the $\mathrm{AB} 0$ system.

\section{Materials and Methods}

The study was conducted in the clinical diagnostic laboratory of the Federal State Budgetary Educational Institution of Higher Education «Samara State Medical University» of the Ministry of Healthcare of the Russian Federation. 89 healthy volunteers (19\% and $81 \%$ women) participated in the study. Their condition was confirmed by the absence of acute and exacerbation of chronic diseases, as well as by the absence of socially significant diseases. The average age of the study group was $27.5 \pm 5.1$ years. Voluntary informed consent to participate in the study of blood and oral fluid was obtained. The study material was venous blood obtained using vacuum blood collection systems and oral fluid collected in a sterile plastic disposable container by spitting. Before oral fluids were taken, all participants were instructed with the rules of preparation and the procedure for collecting oral fluids. Oral fluid was collected in the morning hours, on an empty stomach, not earlier than 15 minutes after teeth cleaning. One hour before collecting oral fluid, the mouth was rinsed with boiled water. Before collecting oral fluid, physical and emotional stress and smoking were excluded. Samples with blood were not accepted for examination [8].

An EDTA tube was used to perform blood group and hematological studies. Blood group determination was performed by agglutination method with the use of monoclonal antibodies anti-A, anti-B, anti-D Super produced by Hematologist Ltd. and a set of standard erythrocytes of $0(\mathrm{I}), \mathrm{A}(\mathrm{II}), \mathrm{B}(\mathrm{III})$ groups produced by State Budgetary Healthcare Institution "Samara regional clinical blood transfusion station". Hematological studies were performed on CELL-DYN Ruby, Abbott Diagnostics automatic hematological analyzer. The secretory status of the oral fluid was determined according to the Vidas method [9]. One milliliter of unstimulated oral fluid was placed in a thermostat at $70^{\circ} \mathrm{C}$ for 10 minutes to cause thermal denaturation of enzymes. Samples taken were then centrifuged for 10 minutes at $1700 \mathrm{rpm}$. Dilution of the obtained supernatant at a ratio of $1: 10$ by the physiological solution of $\mathrm{NaCl}$ was prepared. After dilution, $30 \mu \mathrm{l}$ of the resulting solution were taken in two tubes. Anti-B monoclonal antibodies were added to the first tube and anti-A monoclonal antibodies were added to the second tube. We incubated them for 10 minutes at room temperature. At the end of incubation, a drop of $2.5 \%$ of the blood group B (III) red blood cell suspension was added to the first tube and A(II) blood group was added to the second tube. The control was a physiological solution of $\mathrm{NaCl}$, for which all steps described above were performed. The results were considered according to the standard Vidas method. The results were statistically processed in the IBM SPSS Statistics 23 software. Characteristic distribution was assessed using the Kolmogorov-Smirnov test, intergroup comparisons were performed using the Mann-Whitney test.

\section{Results}

In our study, we found that out of 89 subjects, $42.5 \%$ had blood group 0(I), 31.5\% had blood group A(II), 16.5\% had blood group $\mathrm{B}(\mathrm{III})$, and $9.5 \%$ had blood group $\mathrm{AB}(\mathrm{IV})$, with Rh-positive $82.7 \%$ and $\mathrm{Rh}$-negative $17.3 \%$ (Figure 1). Since the group agglutinogens A and B are mainly localized on the erythrocyte membrane, we have studied the dependence of erythrocyte parameters on the group belonging by the system AB0. The obtained results are presented in Table 1. The highest Red Blood Cell Count (RBC) and Hemoglobin Content $(\mathrm{Hb})$ were observed in the individuals with AB (IV) blood group $\left(4.97 \pm 0.13 \times 10^{12} / \mathrm{l}, 128.5 \pm 5.19 \mathrm{~g} / \mathrm{l}\right)$, but the parameters of Mean Corpuscular Volume (MCV) and Mean Corpuscular Hemoglobin (MCH) in this group were the lowest $(88.15 \pm 2.35$ and $25.92 \pm 0.89 \mathrm{pg}$ respectively). The minimum RBC value was typical for individuals with B (III) $\left(4.72 \pm 0.07 \times 10^{12} / \mathrm{l}\right)$ and 0 (I) $\left(4.73 \pm 0.05 \times 10^{12} / \mathrm{l}, \mathrm{p}=0.001\right)$ blood groups; the minimum hemoglobin concentration was also found in individuals with 0 (I) blood group $(122.24 \pm 2.82 \mathrm{~g} / \mathrm{l}, \mathrm{p}=0.001)$. Besides, this group was characterized by the lowest value of the average hemoglobin concentration (MCHC) $(29.15 \pm 0.25 \mathrm{~g} / \mathrm{dl}, \mathrm{p}=0.001)$.

The presence of antigens A or B in the oral fluid was determined in $44.1 \%$ of cases, while the number of non-secreting antigens is $55.9 \%$. It should be noted that $42.5 \%$ of the examined individuals have 0 (I) blood group, so they cannot be antigen A and B secretors due to their absence on the membrane surface of red blood cells. Thus, the absence of antigens $\mathrm{A}$ and $\mathrm{B}$ in individuals with "nonzero" blood group is observed in $13.4 \%$ of subjects, $9 \%$ of whom are blood group B(III) carriers. The presence of antigen $\mathrm{A}$ in the oral fluid was found in $27 \%$ and antigen B in $7.6 \%$. In $9.5 \%$ of the individuals examined, both antigens are secreted (Figure 2). 
Table 1: Variability of erythrocytic parameters depending on group affiliation according to AB0 system (n=89).

\begin{tabular}{|c|c|c|c|c|c|}
\hline Parameter & Statistical indicator & 0 (I) & $A(I I)$ & B(III) & $A B(I V)$ \\
\hline \multirow{3}{*}{$\mathrm{RBC}, \mathrm{x} 10^{12} / \mathrm{l}$} & $M+m$ & $4.73 \pm 0.05$ & $4.78 \pm 0.07$ & $4.72 \pm 0.07$ & $4.97 \pm 0.13$ \\
\hline & Me [Q1;Q3] & $4.69[4.49 ; 4.86]$ & $4.75[4.46 ; 5.15]$ & $4.67[4.52 ; 5.03]$ & $4.89[4.55 ; 5.19]$ \\
\hline & $\mathrm{p}$ & 0.001 & & & \\
\hline \multirow{3}{*}{$\mathrm{MCV}, \mathrm{fl}$} & $M+m$ & $89.56 \pm 0.8$ & $90.47 \pm 0.62$ & $90.18 \pm 1.29$ & $88.15 \pm 2.35$ \\
\hline & Me [Q1;Q3] & $90.25[87.4 ; 92.75]$ & 90.35 [87.53; 92.9] & $90.9[85.75 ; 94.55]$ & 88.7 [83.73; 95.78] \\
\hline & $\mathrm{p}$ & 0.001 & & & \\
\hline \multirow{3}{*}{$\mathrm{Hb}, \mathrm{g} / \mathrm{l}$} & $M+m$ & $122.24 \pm 2.82$ & $127.7 \pm 1.75$ & $124.95 \pm 2.09$ & $128.5 \pm 5.19$ \\
\hline & Me [Q1;Q3] & $124.5[117.5 ; 131]$ & $124.5[119 ; 135]$ & 123 [119; 132] & $131.5[107.75 ; 142.75]$ \\
\hline & $\mathrm{p}$ & 0.001 & & & \\
\hline \multirow{3}{*}{$\mathrm{MCH}, \mathrm{pg}$} & $\mathrm{M}+\mathrm{m}$ & $26.32 \pm 0.32$ & $26.7 \pm 0.23$ & $26.53 \pm 0.42$ & $25.92 \pm 0.89$ \\
\hline & Me [Q1;Q3] & $26.5[25.55 ; 27.6]$ & $26.6[25.95 ; 27.58]$ & $26.9[25.05 ; 27.85]$ & $27.4[23.15 ; 28.28]$ \\
\hline & $\mathrm{p}$ & 0.001 & & & \\
\hline \multirow{3}{*}{$\mathrm{MCHC}, \mathrm{g} / \mathrm{dL}$} & $\mathrm{M}+\mathrm{m}$ & $29.15 \pm 0.25$ & $29.51 \pm 0.14$ & $29.41 \pm 0.16$ & $29.36 \pm 0.38$ \\
\hline & $\mathrm{Me}[\mathrm{Q} 1 ; \mathrm{Q} 3]$ & $29.3[28.7 ; 29.85]$ & $29.3[28.9 ; 29.9]$ & $29.3[28.9 ; 30]$ & $29.4[28 ; 30.2]$ \\
\hline & $\mathrm{p}$ & 0.001 & & & \\
\hline
\end{tabular}

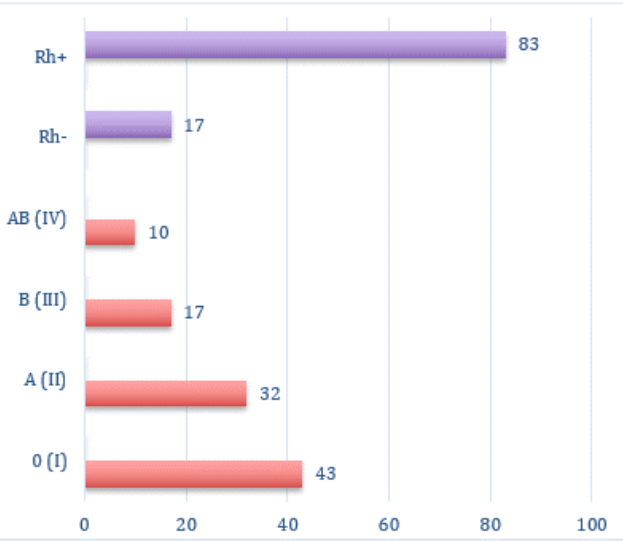

Figure 1: Distribution by blood group (ABO system) and Rhesus factor in the study group.

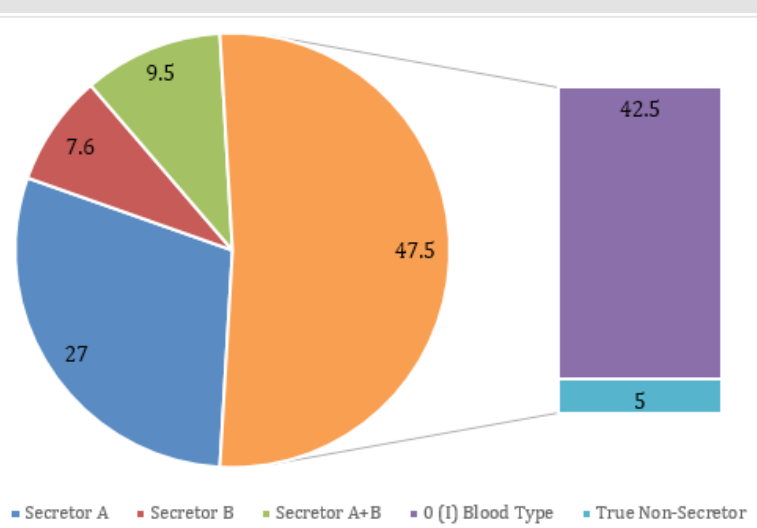

Figure 2: Secretory status of oral fluid by antigenic composition A and B in the study group, \% 


\section{Discussion}

Blood groups according to AB0 system are known to be coded by a gene consisting of three main alleles $(A, B, 0)$ located on the terminal part of the long shoulder of 9 chromosomes (9q.34.2) [10]. The alleles A and B carry different types of glycosyltransferases that catalyze the attachment of $\mathrm{N}$-acetygalactosamine or D-galactose to substance $\mathrm{H}$, which becomes the antigen $\mathrm{A}$ or $\mathrm{B}$ as a result of corresponding transformations. In case the gene allele encodes a non-functional enzyme, the substance $\mathrm{H}$, which is chemically a fucose, remains unchanged.

The source of antigenic determinants of blood groups are water-soluble substances that are found in many biological fluids and organs. For the first time, the presence of antigens A and B in the oral fluid has been described by Yamakami [11], noting also that the antigens in the oral fluid is fully consistent with the antigenic composition of the blood in the case if a person is the secretor. In a recent study of oral fluid proteome [12] it was noted that the composition of glycans differed significantly when comparing secretors and non-secretors.

This is explained by the fact that non-secretors have inactive forms of fucosyl transferase, which provides the construction of a glycanic framework for further transformation of epitopes of molecules. Therefore, non-secretors have less fucosylated derivatives, however, they have a higher content of sialated molecules [13]. In addition, the study of glycome - a set of glycoproteins - of oral fluid in people with different blood groups according to $\mathrm{AB} 0$ system revealed different glycan composition depending on time of day and physical activity [14]. From a functional point of view, the difference in oral fluid composition between secretors and non- secretors causes different resistance to viral and bacterial infections, since changes in the glycoprotein composition of oral fluid can affect the activity of the complement system and the amount of secretory $\operatorname{IgA}[15,16]$.

\section{Conclusion}

a) For the first time we used the Vidas technique to determine the secretory status of oral fluid by A and B antigens.

b) We found out that the blood group affiliation according to AB0 system coincides with antigens A and B secreted into the oral liquid.

c) The number of "true" non-secretors - individuals with "non-zero" blood group, who do not have either A or B antigens in oral fluid was $13.4 \%$, and $9 \%$ of them clinically determined blood type B(III).

Antigens of the $\mathrm{AB} 0$ system are traditionally considered in the context of immunohematology and transfusiology. Recently, however, more and more data on the significance of study in oral fluid have been appearing. These results are of interest not only for practical medicine as a convenient and non-invasive method of diagnosis, but also for solving fundamental problems. Determining the patient's oral fluid glycome as an individual parameter of a particular individual will help to create a qualitatively new personalized approach in preclinical diagnosis and to develop preventive measures for many known diseases.

\section{Conflict of Interest}

There is no conflict of interest or source of funding.

\section{References}

1. Rosin Ya, Gazenko O, Shtern LS (1981) 0 gistogematicheskikh bar'erakh. Gistogematicheskie bar'ery i neirogumoral'naya regulyatsiya. Nauka, Moscow USSR, pp: 180.

2. Chuikin S, Akmalova G (2015) The concept of hemato-salivary barrier. Meditsinskii vestnik Bashkortostana 5(59): 103-107.

3. Bykov V (2015) Gistologiya i embrional'noe razvitie organov polosti rta cheloveka. GEOTAR-Media, Moscow, Russia, pp: 230.

4. Ruvinskaya G, Mukhamedzhanova L (2013) Hemato-salivary barrier: morphofunctional features in norm and pathology. Prakticheskaya meditsina 4(72): 21-25.

5. Akmalova GM (2015) Clinical significance of hemato-salivary barrier in some somatic illness. Sovremennye problemy nauki i obrazovaniya 4: 386.

6. Sun F, Reichenberger E (2014) Saliva as a source of genomic DNA for genetic studies: review of current methods and applications. Oral Health Dent Manag 13(2): 217-222.

7. Zhao J, Yang Y, Huang H, Li D (2020) Relationship between the ABO Blood Group and the COVID-19 Susceptibility. Preprint, medRxiv.

8. Bykov I, Ladutko A, Esaulenko E (2008) Biokhimiya rotovoi i desnevoi zhidkosti: uchebnoe posobie. Kachestvo, Krasnodar, Russia, pp: 100.

9. Vidas I, Delajlija M Temmer Vuksan (1999) Examining the secretor status in the saliva of patients with oral pre-cancerous lesions. J Oral Rehabil 26(2): 177-182.

10. Franchini M, Bonfanti C (2015) Evolutionary aspects of ABO blood group in humans. Clinica Chimica Acta 444: 66-71.

11. Thaler R, Froum S, Chuba J (1976) A quantitative study on the relationship of salivary blood group substances to periodontal disease. J Periodontal Res 11(2): 116-120.

12. Albertolle ME, Hassis ME, Jen CN (2015) Mass spectrometry-based analyses showing the effects of secretor and blood group status on salivary N-glycosylation. Clin Proteom 12: 29.

13. Thomsson KA, Schulz BL, Packer NH (2005) MUC5B glycosylation in human saliva reflects blood group and secretor status. Glycobiology 15(8): 791-804

14. Kozak RP, Urbanowicz PA, Punyadeera C (2016) Variation of Human Salivary 0-Glycome. PLoS ONE 11(9): e0162824.

15. Gunput ST, Wouters D, Nazmi K (2016) Salivary agglutinin is the major component in human saliva that modulates the lectin pathway of the complement system. Innate Immun. 22(4): 257-265.

16. D Adamo P, Kelly GS (2001) Metabolic and immunologic consequences of ABH secretor and Lewis subtype status. Altern Med Rev 6(4): 390-405. 
ISSN: 2574-1241

DOI: 10.26717/BJSTR.2020.26.004424

F Gilmiyarova. Biomed J Sci \& Tech Res

(C) P) This work is licensed under Creative

Submission Link: https://biomedres.us/submit-manuscript.php

$\begin{array}{ll}\text { BIOMEDICAL } & \text { Assets of Publishing with us } \\ \text { RESEARCHES } & \text { - Global archiving of articles } \\ & \text { - Immediate, unrestricted online access } \\ & \text { - Rigorous Peer Review Process } \\ & \text { - Anttps://biomedres.us/ }\end{array}$

